Relations industrielles

Industrial Relations

\title{
Johnston, Paul, Success While Others Fail: Social Movement Unionism and the Public Workplace
}

\section{Anne Forrest}

Volume 51, numéro 2, 1996

Nouveaux modèles de négociation, de résolution de conflits et de solutions conjointes de problèmes

New Models of Negotiations, Dispute Resolution and Joint Problem

Solving

URI : https://id.erudit.org/iderudit/051106ar

DOI : https://doi.org/10.7202/051106ar

Aller au sommaire du numéro

Éditeur(s)

Département des relations industrielles de l'Université Laval

ISSN

0034-379X (imprimé)

1703-8138 (numérique)

Découvrir la revue

Citer ce compte rendu

Forrest, A. (1996). Compte rendu de [Johnston, Paul, Success While Others Fail: Social Movement Unionism and the Public Workplace]. Relations industrielles / Industrial Relations, 51(2), 424-426. https://doi.org/10.7202/051106ar

Tous droits réservés @ C Département des relations industrielles de l'Université Laval, 1996
Ce document est protégé par la loi sur le droit d'auteur. L'utilisation des services d'Érudit (y compris la reproduction) est assujettie à sa politique d'utilisation que vous pouvez consulter en ligne.

https://apropos.erudit.org/fr/usagers/politique-dutilisation/ 
désapprobation, du moins je l'espère. L'attitude normale aurait été le refus, je pense mēme qu'un tel ordre n'aurait jamais été donné. Par ce type de test mon rôle était mieux identifié, par élimination en quelque sorte. Je ne venais pas faire un contrôle d'hygiène et je n'ai rien révélé de cette expérience aux responsables hiérarchiques. (p. 91)

Les conclusions que les employés de l'entreprise devaient tirer de leurs observations de ce comportement de la part de l'ethnologue sont pour le moins troublantes, tant au niveau de sa responsabilité éthique qu'au niveau de son jugement scientifique plus généralement parlant. Quelle crédibilité pouvait lui être attribuée? Il est probable que les perceptions des employés quand à la validité de cet acteur organisationnel aient influencé leurs comportements en sa présence de manière à porter atteinte à la fidélité des résultats de l'étude.

La citation suivante, tirée de l'introduction à la première partie de l'ouvrage, résume la principale préoccupation de cette critique:

Il arrive souvent, en morphologie, que la tâche essentielle consiste à comparer des formes voisines, plu- tôt qu'à définir chacune avec précision; et les déformations d'une figure compliquée peuvent être un phénomène facile à comprendre, bien que la figure elle-même doive rester non analysée et non définie. (d'Arcy Wentworth Thomson, On Growth and Form, Cambridge University Press, Volume II, p. 1032; cité par Claude Lévi-Strauss dans Anthropologie Structurale, Librairie Plon, 1958, p. 384)

Cette citation hors de son contexte évoque la spécification d'une forme complexe en elle-même et en comparaison avec d'autres formes voisines en morphologie. Quelque peu paradoxalement, en son contexte, cette même citation met en valeur la plus importante faiblesse de l'étude de Nicole Fazzini-Feneyrol : l'inadéquate attention au modèle théorique sous-jacent à la compréhension du changement organisationnel qui permettrait d'identifier les cas voisins en fonction de leur nature commune. Sans un tel modèle théorique, l'analyse et la comparaison des cas organisationnels de "formes voisines " devient impossible.

ANN C. SÉROR Université Laval

\section{Success While Others Fail: Social Movement Unionism and the Public Workplace}

by Paul JOHNSTON, Ithaca, N.Y., ILR Press, 1994, 262 p., ISBN 0-87546-334-7 and ISBN 0-87546-335-5 (pbk.).

In this book, Paul Johnston seeks to explain why certain groups of public sector workers have been successful in negotiating improved terms and conditions of employment while others have failed. He concludes that success falls to those who frame their demands as in the public interest and who ally themselves with others employed in the same agency (and sometimes with managers and administrators), but most importantly with citizen groups in the local political community. He grounds these conclusions in four case studies designed to compare and contrast the relative success and failure of five groups of service workers employed in both the public and private sector in California during the 1980s.

For the author, this inquiry is about much more than finding answers to interesting scholarly questions. Johnston is a committed activist for social change and it is this impulse which informs his study. For many years he was employed as a union organizer and staff representative, so explains that he undertook this research with a view to helping public sec- 
tor unions organize more effectively. His involvement in some of the disputes analyzed in the book was not as a participant-observer as traditionally understood - that is, he was not a participant for the purpose of observing - rather, his involvement preceded by a number of years his decision to pursue an academic career. The distance in time and emotion afforded by the break, he argues, allowed him to combine the benefits of immediate connection and intimate knowledge of the issues under study with the scholarly detachment that comes with reflection and investigation. (For those readers interested in, or concerned about the problems of being an "involved" scholar, Johnston addresses the issue of bias - his own and others' - at some length in chapter 2.)

In my opinion, the author's experiences as a union activist offers the reader a clear understanding of the connection between theory and practice. Johnston describes how his involvement in the dayto-day struggles of public sector workers caused him to reconceptualize the possibilities for union action and power. $\mathrm{He}$ argues that public sector unionists have unwittingly "inherited [the] scripts of business unionism" (p. 37) that do not reflect the economic and political forces which shape labour relations in the public sector. Conventional union wisdom emphasizes the need to organize across the labour market and the importance of the strike as the all-powerful weapon in collective bargaining. In his experience, neither was imperative (or even helpful) in the disputes in which he took part.

Appealing to workers' common occupational interests did not enhance workers' bargaining power, Johnston argues. Rather, public sector workers were most successful when they united across occupational divisions within public sector agencies and reached outside the workplace to involve themselves in broadbased coalitions of community groups around community needs. Thus, teachers and school bus drivers were more likely to win their bargaining demands when they allied themselves with parents to express their common concerns about the quality of education and the safety of children. He observed that narrowly articulated economic demands were often a political liability, while "the same demands framed, for example, as 'comparable worth' could serve as a 'club' with almost palpable power" (p. 40). Strikes were frequently a liability as well for the afforded politicians and agency managers the opportunity to mount public relations campaigns blaming unreasonable unions for tax increases and the fiscal crisis. Over time, Johnston reports that unions learned to conduct strikes, not as economic actions, but as political mobilizations. "Annual elections and the battle of the budget,' which annually set levels of staffing and service as well as pay, became as important as contract negotiations" (p. 41).

Johnston underscores the limitations of conventional industrial relations analysis of labour relations in the public sector. In his view, there is a "great body of research" with "many false starts but no compelling theory" (p. 27). He attributes this lack of success to the intellectual insularity of scholars in the field whose thinking remains uninformed by recent developments in state theory, urban political sociology, organization theory, feminist theory, and the study of social movements. He is especially criti$\mathrm{cal}$ of the managerial bias which underpins much of the research. He argues that scolars have been too willing to define the growing militancy of public sector unions as a social problem and to formulate solutions - such as withdrawing the right to strike - without view to solving management's problem without considering how such solutions undermine the terms and conditions of employment of public sector workers.

It is not coincidence that the bargaining disputes chosen for analysis were rooted in the discontents of women and men of colour. What Johnston describes 
is the slow erosion of the white male, blue-collar worker alliance with construction and real estate interests that dominated cities in California (and elsewhere) until the 1970s. Only by analyzing the politics of growth and austerity, he argues, is it possible to understand how some women workers were able to win substantial comparable worth adjustments during a period of austerity while other segments of public sector, namely, Mexican-American janitors and custodians, saw their jobs subcontracted and their pay cut in half. In exploring these radically different outcomes Johnston presents a finely tuned analysis of the disputes involving women workers; however, he is much less effective in explaining why men of colour lost out - a limitation of the book which the author acknowledges.
To conclude, Success While Others Fail is a provocative book by an engaged scholar. It is also timely, for it pertains to our own struggles as academics and public sector workers. If Johnston is right, we are badly advised to fight cut-backs by complaining about our deteriorating terms and conditions of employment, however justified these complaints might be. Arguably, academics would be more successful if we were to reach out to potential allies in the wider community who share our concerns about quality and access to post-secondary education. According to Johnston, such a strategy would contribute to building the social consensus that we, and other public sector workers, need to initiate change.

ANNE FORREST University of Windsor

\section{La problématique du sida en milieu de travail : pour l'employé, l'em- ployeur et les tiers \\ par Sylvie GRÉGOIRE, Montréal, Wilson \& Lafleur, éditeur, 1994, 196 p., ISBN 2-89127-291-9.}

Dans cet ouvrage, l'auteure Sylvie Grégoire aborde l'épineux sujet du sida en milieu de travail. Cette maladie qui hante cette fin de siècle soulève évidemment d'importantes questions d'ordre médical et social. Elle pose aussi des problèmes en milieu de travail dont les solutions demeurent souvent imprécises, voire même sans réponse. L'ouvrage recensé traite particulièrement des aspects juridiques liés au sida en milieu de travail. Tout en situant cette maladie dans ses dimensions médicale et sociale, l'auteure traite de façon judicieuse et approfondie des obligations et des droits respectifs des personnes confrontées au sida dans leurs relations de travail, qu'il s'agisse de l'employé porteur ou atteint de la maladie, de l'employeur, de ses collègues de travail ou du public requérant ou utilisant les services de l'entreprise.

L'étude comprend deux chapitres. Dans le premier chapitre, l'auteure explique d'abord les aspects médicaux du sida : ses différentes phases de développement et ses conséquences sur les capacités physiques et intellectuelles de la personne qui en est atteinte. Elle expose, en deuxième lieu, la problématique du sida en milieu de travail, notamment les craintes qu'engendre cette maladie et les coûts économiques et sociaux qu'elle entraîne. L'auteure traite ensuite de la qualification juridique de l'état de santé de la personne porteuse ou atteinte du sida. Est-ce un 'handicap' ou une 'déficience' selon les lois sur les droits de la personne? Cette section est particulièrement intéressante parce que l'auteure procède à une comparaison de la situation canadienne, québécoise et américaine des législations et de la jurisprudence traitant de cette question. L'auteure démontre que la personne ayant développé des symptômes ou la maladie du sida ne peut subir, en vertu des lois sur les droits de la personne, de discrimination pour ce motif. Toutefois, cette interdiction de discrimination pourra être écartée si 